\title{
Challenges for Police Leadership: Identity, Experience, Legitimacy and Direct Entry
}

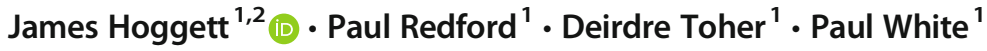 \\ Published online: 19 March 2018 \\ (C) The Author(s) 2018
}

\begin{abstract}
The police service in England and Wales has developed a new approach to police leadership where individuals from outside of the police service can now enter directly to leadership ranks. Previous research identified that officers place great value on being led by someone who has experience of being a police officer. Adopting a social identity perspective, the current paper reports on quantitative and qualitative data about police officer views on direct entry and existing police leadership captured as part of a wider national survey $(N=12,549)$ of police officers in England and Wales. The paper identifies the importance that shared identity and credibility play in police follower/leadership relationships. It argues that direct-entry police leaders face credibility issues linked to their lack of shared police identity but also that serving officers perceive existing leaders to be poor because they believe they have forgotten what it is like to be a police officer. This paper develops a new theoretical and empirical approach to police leadership utilizing social and organizational psychology theory and research. The paper suggests that if police leaders understand police identity, then they can create propitious conditions within which police officers will follow their leaders.
\end{abstract}

Keywords Police leadership $\cdot$ Police identity $\cdot$ Direct entry $\cdot$ Police followership $\cdot$ Social identity theory

\section{Introduction}

Recent developments to the police service in England and Wales have led commentators to suggest that it is facing some of the biggest and most controversial challenges in the last 60 years (Brain 2013). Government austerity measures required the police service to find total savings of $£ 2.42 \mathrm{bn}$ by 2015 (Her Majesty's Inspectorate of Constabulary 2013) while a recent comprehensive review of police officer and staff pay and conditions suggested substantial reform to policing was needed (Winsor 2011, 2012). The police service also faces increased demand for accountability in relation to issues such as the emergence of new crime types and public legitimacy issues (College of Policing 2015). In order to respond to such challenges, police leadership has emerged as a focal point for development. As Peter Neyroud (2011, p.2) states

James Hoggett

james.hoggett@uwe.ac.uk

University of the West of England, Bristol, UK

2 Faculty of Health and Social Science, Frenchay Campus, Coldharbour Lane, Bristol BS16 1QY, UK in his Review of Police Leadership and Training for the Home Secretary,

I have concluded that, in the light of the government's published ambitions for policing and the challenges that policing needs to meet, this is a moment for radical change in the approach to police leadership and training

\section{Leadership in Policing}

Police leadership has long been an area of interest for academic research (Bryman et al. 1996; Kerr and Jermier 1978). While effective leadership appears such a desired commodity within policing, limited scholarly attention has been given to studying leadership processes and the barriers to developing more efficacious leadership practices (Mastrofski 2002, 2006). Instead, police leadership research appears to be dominated by a focus on individual idiosyncratic leader traits, characteristics, and behaviors (Schafer 2009, 2010), which can be traced to traditional leadership theories and are not reflective of the substantial developments on leadership research and theory that have occurred in the last decade (Dinh et al. 2014).

More recently, two models have dominated police leadership research (Dobby et al. 2004). The first is based on notions 
of transaction between leaders and specific followers in which leaders provide rewards to followers and in return followers "allow" leaders to lead (Bass 1985). The second focuses on the role of charisma, as a largely individual characteristic which enables leaders to transform groups and organizations (Berson et al. 2006; Judge et al. 2002). As Bill Bratton, the former NYC police commissioner, stated in an interview with the Guardian newspaper, "Bureaucrats change processes, leaders change culture. I think of myself as a transformational leader who changes cultures" (Dodd and Stratton 2011). However, despite an apparent shift towards such models of leadership in policing, particularly the transformational model, little evidence has been found to suggest that such leadership style has transformed police culture (Cockcroft 2014).

As part of the Independent Review of Police Officer and Staff Remuneration and Conditions (Winsor 2011, 2012), entry routes to the police were specifically considered as a means of changing police leadership and culture. From the review, two recommendations were made which are of relevance here. The first was for a national scheme for direct entry (DE) to the rank of superintendent to be established and brought into operation. Participants on the scheme would be persons of exceptional achievement and ability who had been assessed as having the potential to be senior police officers (Recommendation 19). The second was for a new fast track (FT) program that would offer a development program and promotion mechanism to enable the most talented individuals to advance to the rank of inspector within 3 years.

While evidence of the impact and success of these new schemes will obviously take time to emerge debates about the merits of direct entry to policing are not new. In the UK, until around the Second World War, many officers at the highest echelons in county forces were drawn directly from elite and military backgrounds (Leishman and Savage 1993). Fast track promotion schemes also have a long history within UK and US policing. For example, within the UK, the Trenchard scheme (1933) recognized a need to identify talent within the service that should be "fast tracked" to more senior positions - while also attracting qualified individuals from other professions who could add value as leaders and influencers within the service (Boyle 1962). Within the USA, similar drives to attract qualified individuals have been linked to debates about professionalizing policing through educational qualifications, lateral entry, and leadership training such as that provided by the senior management institute for police (Krimmel 1996; Lee and Punch 2004). What all of these approaches have in common is a leader centric focus. They all assume the unique traits, characteristics, and actions of individuals are enough to provide successful leadership in policing (Schafer 2009; College of Policing 2015).

Recent developments in leadership theory have begun to provide a different perspective (Giessner et al. 2009). Drawing from Social Identity Theory (Tajfel and Turner 1979), research has begun to focus on "followership" and the role of those who follow the leader (Haslam et al. 2011). Crucial to this development is the recognition that leadership is not simply related to the characteristics of individuals in positions of relative power but also related to those in subordinate positions and is a dynamic of the relationships between the two (Reicher et al. 2005).

Social identity research suggests that it is by being able to develop and direct a shared sense of "us" that leaders are able to galvanize individuals otherwise idiosyncratic motivations. By doing so they can harness the transformative power of their coordinated energies (Ellemers et al. 2004: Steffens et al. 2014). Consistent with this proposition, research has shown that leaders are more likely to be endorsed by followers to the extent that they are seen to be representative of a common ingroup (Haslam 2001; Platow and van Knippenberg 2001). Where such endorsement happens, research suggests that followers will orient their behavior in the way desired by the leader. In short, it is only when leaders are seen to embody "who we are" that their leadership stimulates followership (Haslam et al. 2011). Research also shows that rather than being an inherent quality of an individual, a variety of stereotypical leader qualities (or traits) are actually the consequence of perceived representativeness. In other words, evidence suggests that we regard leaders as more trustworthy, fair, and charismatic to the extent that they are seen to represent, understand, and advance the interests of a common in-group (Haslam et al. 2001; Platow et al. 2003).

Relating this to the police, research has continually found that frontline officers place great value on being led by senior officers who have considerable direct experience of streetlevel police work (Rowe 2006). Followers identify more strongly with leaders who have shared common experiences because they are deemed more like, and thus more representative of, subordinate officers. Work by Caless (2011), reporting on senior police officer perceptions of leadership, echoes this idea. He found that senior officers believe that there is an exclusivity in policing that can only be understood if you have done the job and where credibility depends on experience of hard-learned and hard-earned knowledge.

Therefore, officers who rapidly climb the promotion ladder, without serving their time on the streets, are regarded with some suspicion. Such suspicion may be particularly acute for the new DE and FT officers who lack this shared police experience and thus group membership. This suggests that efforts will therefore need to be made to bridge what Rowe (2006) calls the credibility gap between frontline officers and these new police leaders. Research has identified a range of strategies that could be adopted to address these credibility issues including making junior officers feel more involved and valued in decision-making processes (Steinheider and Wuestewald 2008) or leaders actively creating organizational contexts that prevent an internal us versus them mentality 
developing between top management and other tiers within the police (Haake et al. 2015; Schaveling et al. 2017).

\section{Aims of Paper}

Reporting on data captured from a national survey of police officers, this paper will examine officer perceptions concerning police leadership and the new direct entry and fast track schemes and will explore issues which affect leader follower relationships. The paper will highlight social identity theory's relevance to police leadership research and practice in terms of not only DE and FT officers but also current police leaders. It will argue that a shift in theoretical and empirical focus may help to maximize the impact DE, FT, and existing police leaders can have in managing and delivering the changes currently facing policing in England and Wales by creating more propitious conditions for police officers to follow their leaders.

\section{Methods}

\section{Design}

This paper analyzes data from a national project that looked at police officers' perspectives on a range of issues facing the police service in England and Wales. The project was funded by the Constables Central Committee (CCC) of the Police Federation of England and Wales and used an online survey questionnaire, the link to which the Police Federation emailed to their membership within all 43 Home Office police forces (including the Metropolitan Police) in England and Wales. The survey was developed using the software package Qualtrics to elicit self-report data from police officers from the rank of Police Constable (PC) to Chief Inspector (CI). The self-report data contained in this paper relate to both quantitative and qualitative survey questions. The quantitative data relates to officers' responses to the following statement, 'The direct entry scheme is a good idea." This question was based on a five-point Likert scale ranging from Strongly Agree to Strongly Disagree. The qualitative data relates to officer's written responses to the following two open questions which were included in the survey, "please state your biggest hopes for the future of your job as a police officer" and "please state your biggest concerns for the future of your job as a police officer."

The qualitative responses of officers were therefore not cued (Zaller and Feldman 1992) to address any specific issue or topic beyond following on from a range of quantitative questions about issues currently facing the police in England and Wales of which direct entry leadership was one topic. Instead, officers were free to raise and discuss any issues that they perceived as important to their hopes or concerns for the future of the police in much the same way that an unstructured interview would within traditional qualitative research (Seidman 2013). Bryman et al. (1996) have previously noted the importance of, and positive impact that, qualitative approaches in police leadership can have, and the current design seeks to build on this.

\section{Sample}

The online survey was e-mailed to serving officers via Police Federation representatives. From a total sample of 13,591 officers, 12,549 completed the quantitative question on directentry leadership (see Table 1) while 11,127 completed the question about their biggest hopes for the future and 11,271 completed the question about their concerns. This sample size is about a one-in-ten response rate when judged against the size of the total eligible police population in England and Wales of 122,859 (Home Office 2017). Analysis of the sample indicated it was representative nationally of the structure of the police in England and Wales in terms of gender and rank and did not vary geographically (Home Office 2017; see Hoggett et al. 2014 for more information).

\section{Analysis}

Officer responses to the Likert scale question on direct-entry police leadership were examined using descriptive statistics to identify overall levels of unanimity in agreement or disagreement to the question and a chi sq test of independence to examine unanimity by gender or rank. Effect size was quantified using Cramer's V, 95\% Clopper-Pearson confidence intervals for a proportion, and the Goodman Kruskal gamma measure of ordinal association $(\gamma)$ which is suitable for fivepoint Likert ordinal data and is interpreted as a correlation coefficient and bounded between \pm 1 . This form of data analysis was chosen to provide a general context to officers' perspectives on police leadership, which in turn helps provide a framework through which to understand officers' responses to the qualitative questions. In other words, the quantitative data identifies what officers think about direct entry police leadership and how representative these views are, while the qualitative data illuminates why they think this.

A combination of data and theory-driven analytical approaches were adopted for the qualitative analysis (Glaser and Strauss 1967; Weber 1990). To extract data relevant to direct entry and police leadership, a simple form of data reduction strategy (Miles and Huberman 1994) using word searches from answers to the two survey questions was used. After initial reading of the data, the words used to search the data were direct entry/fast track (hopes $=194$ entries, concerns $=647$ entries $)$, Association of Chief Police Officers $/$ ACPO $($ hopes $=111$, concerns $=130)$, support $($ hopes $=$ 1473 , concerns $=1320$ ), management (hopes $=368$, concerns $=490$ ), and leadership (hopes $=109$, concerns $=163$ ). 
The numbers by each entry demonstrate the number of officers that used these words in their answers not the total number of times the words were used by officers.

Data extracts containing these words were then identified using the "Find" or "Advanced Find" tools on Microsoft Word (La Pelle 2004; Firmin et al. 2017). The data extracts were subsequently copied and pasted into new Word documents which were given the title of the word used in the initial word search together with the prefix "hopes" or "concerns." For example, a new Word document titled "Concerns ACPO" was created. These new word documents were then analyzed using principles broadly within the tradition of thematic analysis (Braun and Clarke 2006).

\section{Results}

The analysis of data is divided into three parts. First, officer responses to the Likert scale question about direct-entry police leadership will be analyzed using frequencies and chi sq. tests. Secondly, in light of this, officers' qualitative perspectives on DE and FT police leadership will be analyzed before, thirdly, officers' views of current leadership are examined. The analysis will seek to identify the relevance of the concepts of shared group identity and representativeness for leadership success by looking at issues of experience, trust, credibility, support, and the importance of knowing or understanding what it is like to be a police officer.

\section{Quantitative Analysis}

The national survey included a Likert scale statement that related to the issue of direct entry police leadership. The statement was "Direct entry police leadership is a good idea" and officers responded by reporting their level of agreement (strongly disagree to strongly agree) with the statement. Table 1 identifies levels of agreement, the number of officers that reported this level of agreement, and the total number of responses to the question.

Breaking down responses to the question by gender and rank allows us to examine any patterns of agreement or disagreement within the data by key demographics. Table 2 illustrates responses by gender and Table 3 illustrates responses by rank.

A chi-square test for independence indicated a significant association between gender and level of agreement to the statement the direct entry scheme is a good idea, $\chi^{2}=53.2$, $d f=4, p=.001$, Cramer's $V=0.06, \gamma=0.11$. To understand the nature of this relationship, we can look at the standardized residuals with Agresti (2007) noting that any cells having an absolute standardized residual value in excess of about 3 indicates lack of fit (p. 38). On this basis, a lower proportion of female officers than expected $(n=1337,48.7 \%$; $95 \%$ CI 46.8 to $50.6 \%$ ) strongly disagreed that direct entry was a good idea compared to male officers $(n=5283,55.5 \% ; 95 \%$ CI 54.5 to $56.5 \%$ ). In addition, a higher proportion of female officers $(18.3 \%, 95 \%$ CI 16.6 to $19.8 \%)$ than male officers $(13.6 \%$, 95\% CI 13.0 to $14.4 \%$ ) neither agreed nor disagreed that direct-entry leadership was a good idea. However, only $4 \%$ of male officers and $3.9 \%$ of female officers agreed or strongly agreed that DE leadership was a good idea.

A chi-square test for independence indicated a significant association between rank and level of agreement that the direct entry scheme is a good idea, $\chi^{2}=33.5, d f=4, p=.001$, Cramer's $V=0.05, \gamma=0.06$. Analysis of the standardized residuals indicates those of management rank Sergeant to Chief Inspector were less likely to state that they neither agreed nor disagreed $(11.5 \%, 95 \%$ CI 10.3 to $12.7 \%)$ with the statement than police constables $(15.8 \%, 95 \%$ CI 15.1 to $16.6 \%)$. In addition, only $3.9 \%$ of police constables and $4.1 \%$ of Sergeants to Chief Inspectors agreed or strongly agreed that the direct entry scheme was a good idea.

\section{Qualitative Perspectives on Direct-Entry and Fast-Track Police Leadership}

\section{Experience}

When expressing their views on DE and FT, a key issue of concern for respondents was about the lack of policing experience these individuals would have. Experience was viewed as vital for operational competence and for delivering performance outcomes. Concerns about senior officers who have no policing experience were frequently raised in officers' answers. For example;

Direct entry supervisors, the notion does not respect the level of experience required to make a competent police officer. Experience is an officer's greatest tool.

And;

The role of a police officer is unique by its very nature and only by experience can you hope to lead your
Table 1 Overall levels of agreement that the direct entry scheme is a good idea
The direct entry scheme is a good idea

\begin{tabular}{llllll}
\hline Strongly disagree & Disagree & Neither agree nor disagree & Agree & Strongly agree & Total \\
$6740(53.7 \%)$ & $3454(27.5 \%)$ & $1862(14.8 \%)$ & $405(3.2 \%)$ & $88(0.7 \%)$ & 12,549 \\
\hline
\end{tabular}


Table 2 Gender and direct entry (count, percentage, and standardized chi-square residual)

\begin{tabular}{|c|c|c|c|c|c|c|}
\hline \multirow[t]{2}{*}{ Sex } & \multicolumn{6}{|c|}{ The direct entry scheme is a good idea } \\
\hline & Strongly disagree & Disagree & Neither agree nor disagree & Agree & Strongly agree & Total \\
\hline Male & $5283(55.5 \%)$ & $2563(26.9 \%)$ & $1299(13.6 \%)$ & $310(3.3 \%)$ & $64(0.7 \%)$ & 9519 \\
\hline Residual & 2.0 & -0.9 & -2.6 & 0.1 & -0.3 & \\
\hline Female & $1337(48.7 \%)$ & $798(29.1 \%)$ & $501(18.3 \%)$ & $86(3.1 \%)$ & $22(0.8 \%)$ & 2744 \\
\hline Residual & -3.7 & 1.7 & 4.9 & -0.3 & 0.6 & \\
\hline
\end{tabular}

officers and deliver performance without compromise to the public.

\section{Decision Making}

Lack of experience linked to another area of concern raised by officers. That lack of policing experience would make these individuals poor decision makers. Decision making was discussed in terms of the negative impact it would have on the people they would lead as well as the wider public. As an officer stated;

Direct entry at senior ranks will lead to extremely poor decision making around all aspects of policing that could have untold damage and impact on communities. Intelligence and qualifications are important in leadership and have their place, but the value of experience cannot be ignored either. There is no substitute to experience in all walks of life and the lack of it will always lead to errors and mistakes. In policing terms this is a very serious issue.

Concerns about decision-making capabilities of DE and FT officers were repeatedly raised by others. For example;

Direct entry for either Inspectors or Superintendents will negate the positive impact that experience has on the decision making process in often dynamic and sensitive situations. Ultimately, investigations will fail and members of the public will suffer harm if this policy continues. Direct entry will sacrifice operational effectiveness for budgetary business administration skills.
As well as concerns about the potentially negative impact that poor decision making due to lack of policing experience could have on the public, officers repeatedly discussed their concerns about the impact it would have on themselves and their colleagues. For example, officers raised concerns about;

Direct entry to senior rank of persons who have never walked a beat, fought a violent offender, stood on a cordon for 12 hours freezing their nuts off or who have no real idea of what the 'frontline' is actually like whilst making decisions that affect my safety and well-being.

Similarly, another officer discussed that;

To do the job as a police officer, you need to be a police officer first. Decisions made by senior officers affect those still on the streets, and I feel that direct entry officers will not have that policing experience and will be making decisions from desk top scenarios or book led models, not from experience as a copper.

\section{Earning Rank}

Another issue linked to DE and FT officers and their lack of police experience is that they would not have earned their position and therefore were less deserving of it than officers who had put in the time. As an officer explained;

Rank needs to be earned - automatic entry into higher ranks is a major kick in the teeth for hardworking and deserving officers. Rank must be earned by practical policing experience and studying.

Table 3 Rank and direct entry (count, percentage, and standardized chi-square residual)

\begin{tabular}{|c|c|c|c|c|c|c|}
\hline \multirow[t]{2}{*}{ Rank } & \multicolumn{6}{|c|}{ The direct entry scheme is a good idea } \\
\hline & Strongly disagree & Disagree & Neither agree nor disagree & Agree & Strongly agree & Total \\
\hline $\mathrm{PC}$ & $5145(53.1 \%)$ & $2627(27.1 \%)$ & $1533(15.8 \%)$ & $310(3.2 \%)$ & $66(0.7 \%)$ & 9681 \\
\hline Residual & -0.8 & -0.7 & 2.5 & -0.1 & -0.2 & \\
\hline Sergeant to Chief Inspector & $1595(55.6 \%)$ & $827(28.8 \%)$ & $329(11.5 \%)$ & $95(3.3 \%)$ & $22(0.8 \%)$ & 2868 \\
\hline Residual & 1.4 & 1.3 & -4.7 & 0.3 & 0.4 & \\
\hline
\end{tabular}


The idea that by not earning their rank DE officers would devalue the job of a police officer was one that was frequently raised as a concern by officers;

The direct entry scheme in my opinion devalues the knowledge that is gained as a police officer. Why should I study for promotion when others can come straight in and make decisions based on non-police qualifications?

Another officer contextualized the devaluing impact they felt FT and DE officers would have on people already within the police;

I don't oppose accelerated promotion in principle. However, I feel that direct entry to senior level policing is fundamentally flawed. I cannot foresee how any person can enter the police force as an Inspector or higher, without having spent a substantial amount of time on the street. Direct entry, will further demoralize the service, and will also severely restrict promotion opportunities for existing officers.

\section{Credibility, Respect, and Trust}

One of the most common issues of concern that officers described was that lack of experience would lead to a lack of credibility and respect being shown to FT and DE officers. In turn, it was suggested that this would affect junior officers' willingness to trust and thus follow their leadership. As an officer noted;

You cannot order and expect others to do what you have not done yourself. This isn't a business with little risk. People's lives greatly depend on the experience and actions of Police Officers.

Similarly, another officer described how;

Senior staff are respected not only for their rank, but for the simple fact that they have experienced this job as a constable. There is no way that someone who has been employed directly to a senior rank will have achieved this and therefore the 'rank and file' officers will simply not engage with them.

While another stated that;

No amount of college based training will make up for having no street experience. Any frontline officer worth their salt will tell you that the senior officers we trust and respect are those who come from being a good street copper.
Officers described how it was precisely because DE officers lacked experience of the job and therefore lacked understanding of the issues affecting those they would lead that junior officers would not follow their leadership. For example, an officer noted;

The Direct entry scheme is farcical. How they are able to lead a team of truculent and petulant officers without any understanding of what they are going through on the job is unbelievable. I have respect for senior offices when I have seen them in action throughout their career. I am unlikely to have respect for a senior officer whether direct from university or from WH Smiths.

Finally, officers noted how this lack of credibility and respect in the eyes of junior officers could lead to problems in creating a clear direction and vision for the police service. This is particularly interesting given that this is one of the key drivers of the development of FT and DE programs in the first place. For example, an officer described how;

Direct entry senior officers will result in a lack of proper direction for lower ranking officers as you need to understand the grass roots issues before addressing them. They will also suffer from a lack of credibility. In most, but I accept not all, instances if you haven't experienced police work you can't effectively expect to lead a team dealing with it.

\section{Qualitative Perspectives on Current Police Leadership}

\section{Experience}

When discussing current police leadership, it was the fact that these officers had experience that was perceived as their most desired quality. Officers also discussed how experience was something they hoped that future leaders would have. For example, an officer described how they hoped for;

Leadership by experienced and skilled officers who have performed those roles.

While another officer noted how in the future they hoped that;

Officers who become ACPO first prove themselves as frontline police constables and work through each rank. This way I believe the senior officers have a better perspective on how the police should be run. 


\section{Understanding Frontline Issues}

Respondents reported it was only through experience that police leaders could fully understand frontline officers and therefore be seen as good leaders. For example, an officer stated their hope for;

Stronger leadership from senior managers and recognition of the current feeling amongst police officers and staff.

However, when leaders were unable to demonstrate that they understood these issues, concern was expressed about their suitability to lead. An officer summarized this position succinctly stating that;

I'm concerned about police leadership for the future. It's quite obvious that there are a lot of senior officers who have failed to stand up and say to their officers on the ground, 'chin up, it's going to be a tough few years but I'm right with you.' I've not seen sight of my chief for the last year, as far as I'm concerned we are a leaderless force apart from the odd email from a senior member of civilian staff to tell us about yet another change for the better.

\section{Forgetting What it Is like to Be a Police Officer}

While officers expressed concerns about FT and DE leaders' lack of experience, it appears they also have concerns about current police leadership, which is perceived to be failing junior officers. Officers suggested that a lack of understanding or at least lack of acknowledgment of officer values and feelings was creating a gap between current leadership and the officers they command and that this was having a detrimental impact on the police service. For example;

I fear that there is a massive gap between our Senior Leadership Team and the ground level. There are rifts forming between departments and individuals on a regular basis and officers now just want to do the minimum and move on, rather than put the extra effort in.

One of the reasons that officers repeatedly gave for their views about current poor police leadership is that they believe that senior leaders are out of touch with street-level policing and thus have forgotten what it is like to be a cop. In this situation, as is the case with a lack of experience for FT and DE leaders, junior officers appear to lack respect for police leaders, doubt their credibility, and find it difficult to trust and follow their leadership. As an officer noted;
Senior officers quite frankly seem to have forgotten where they have been.

While another discussed concern that;

All managers past a certain level tend to look after themselves, are only concerned in results that make them look good and not what is actually happening on the ground.

Similarly, another described how they hoped that;

ACPO remember they are police officers, NOT politicians and, that they begin fighting for the benefit of the police and the public we serve as opposed to that of their political futures.

The result of senior leaders forgetting what it is like to be a police officer appeared to create a lack of support for current leadership. As an officer noted;

I have no confidence or trust in my senior command team or the decisions they are making, this does nothing for my confidence or good will towards my force.

While another discussed how;

Leadership is sadly lacking in the Police service and this needs to be addressed immediately. I have never experienced such poor leadership.

\section{(Re) Earning Credibility, Respect and Trust}

The question raised is that if officers have concerns about both FT/DE and current police leadership, what is it they want from their leaders, and how could this be achieved? It appears that officers want leaders who understand the views and experiences of the staff they lead, can communicate with them clearly, and demonstrate a commitment to doing what is best for their staff and the public even when doing so may cause them problems. For example, an officer noted that they want;

Greater and more open and honest support and dialogue between staff and the ACPO ranks.

Similarly, another officer noted that they hoped for;

Clear and positive leadership demonstrating a clear vision from senior management.

In summing up, the generality of this feeling an officer described how they; 
Would like senior police officers to stand behind the rank and file as have senior armed forces officers. I would be concerned if they do not and hope they can acknowledge that the cuts are affecting morale and the service to the public.

\section{Discussion}

From examination of responses to the statement that "the direct entry scheme is a good idea," it can be seen that over $80 \%$ of the 12,549 reported that they either strongly disagreed or disagreed. When broken down by gender and rank, some statistically significant differences were noted, but the effects of these differences are small at best. For example, more female officers than male officers were indifferent to direct entry and less female respondents strongly disagreed that direct entry was a good idea. However, such focus on difference may be slightly misleading as when looking at the percentage responses, it can be seen that only $4 \%$ of male officers and $3.9 \%$ of female officers strongly agreed or agreed that direct entry was a good idea. In terms of rank, more Sergeants to Chief Inspectors than Police Constables were indifferent to direct entry. Similarly, to gender, when looking at percentage responses by rank, it can be seen that difference between ranks in terms of strongly agreeing or agreeing that direct entry is a good idea is low with only $3.9 \%$ of Police Constables and $4.1 \%$ of Sergeants, Inspectors, and Chief Inspectors strongly agreeing or agreeing. This suggests there is a high level of unanimity between male and female officers and those of different rank in lack of support for direct-entry leadership.

The qualitative analysis helped to make sense of this. When discussing DE and FT leaders, it was not their individual traits or characteristics that concerned junior officers, nor the style of leadership they would bring to the police, but rather their lack of police experience. Policing was perceived as something unique (Caless 2011), and previous experience of being a police officer appears central to officers' judgments about the credibility of police leaders. This suggests that the credibility gap (Rowe 2006) that DE and FT leaders face needs to be recognized and addressed rather than dismissed. It is the perception of a shared history and experience that appears to impact on who officers categorize as similar or different to them. In turn, who they categorize as similar or different to them impacts upon who can and cannot influence them (Subašić et al. 2011) and therefore who will and will not be an effective leader (Steffens et al. 2014). In Social Identity terms then because DE and FT leaders lack police experience, they are seen as different from other officers and not part of the same common in-group identity (Reicher et al. 2005). Because of this, their ability to successfully create propitious conditions for followership may at first be limited. What the analysis suggests therefore is that DE and FT officers need to find ways in which they can convince followers that they are representative of them before they can lead them (Haslam et al. 2011). Previous research such as Steinheider and Wuestewald (2008) suggests that creating a model for shared leadership might be one such way of enabling senior officers to understand junior officer perspectives and create an inclusive vision of policing and how it can best be achieved which is seen as representative.

The analysis also reveals that it is not just DE and FT police leaders that face identity and credibility issues. Where officers believe that current police leaders have forgotten what it is like to be a police officer, they also deem them unrepresentative, lacking credibility, and therefore poor leaders. This is important, as research has shown that leaders who are seen to embody the group identity can make decisions and enforce actions that would be seen to go against the interests of the group if made by anyone else. In other words, by being seen as representative, leaders can positively influence follower perceptions of the fairness and necessity of their decision making (Platow and van Knippenberg 2001), which in a period of rapid change and uncertainty may be particularly important to the effective functioning of the police service.

The current study suggests that officers feel that police leadership is failing to comprehend the issues they are currently facing and therefore does not provide the support and recognition officers want from their leaders. Existing police leadership is seen to have failed to represent officers lived experiences which means that they are unable to embody who the police are and thus stimulate followership (Haslam et al. 2011).

Analysis also suggests however that there is an opportunity for DE, FT, and existing police leaders, created by the current conditions of change and uncertainty within the police service to create a clear vision for the police. This vision, if seen to be inclusive of and developed from rank-and-file officers as well as police leaders could help stimulate followership and lead the service through the challenges and changes it is facing (Toch 2008; Sklansky and Marks 2008; Steinheider and Wuestewald 2008; Wood et al. 2008). Where followers perceive that the leader is acting for the group rather than themselves, because they are attuned to what matters to the group, and are believed to be committed to advancing their cause, then followers will embrace the leader's vision as their own (Haslam et al. 2011). Police leaders can therefore become active agents in the leadership process by both knowing how to configure their own behaviors in relation to their junior officer's identity and also involve these officers in decisionmaking processes.

Research suggests there are a number of ways police leaders can seek to achieve this. For example, by creating organizational contexts that seek to unify officers (Haake et al. 2015), giving officers an outlet for their voices to be heard, listened to, and utilized in decision-making processes 
(Steinheider and Wuestewald 2008) or through demonstrating increased social support from within the organization, developing open consultative communication strategies, and demonstrating trust in junior officers (Finn 1997; Anderson et al. 2002). However, to fully embrace and embed such developments, there is also a requirement to recognize the need to make changes to police leadership training to move away from a solely trait-based leader centric focus. Instead, approaches that appreciate the importance of identity and the dynamics of leader-follower relations in the leadership process should be incorporated. That way, organizations such as the College of Policing in the UK or the Senior Management Institute for Policing in the USA can provide a foundation for new leadership approaches to the culture of police leadership in general.

While this paper has argued throughout that identity dynamics are key drivers for successful leadership, it is important to note that the research underpinning this paper was carried out in a climate of rapid change and uncertainty in the police in England and Wales. Within this context, it is possible that other dynamics beyond identity and leader-follower relations might be influencing officer attitudes about leadership. For example, job satisfaction is low as is morale among the police in England and Wales (Hoggett et al. 2014). Therefore, it is important to recognize alternate explanations for the findings in this paper and future research could aim to investigate what other factors influence perceptions of leadership effectiveness as well as how they relate to identity issues. However, analysis identified a level of uniformity across ranks and gender, as well as geographically, which suggests that understanding the views and experiences of junior officers and demonstrating their value within decision making creates credibility and trust and thus more propitious leadership conditions.

\section{Conclusion}

As previous research has illustrated, identity plays an important role in policing (Van Maanen 1978a, b; Hoggett et al. 2014). This paper has also highlighted its relevance to police leadership in terms of whom officers will see as credible, whom they will respect and therefore whom they will trust and follow. It has identified that officers are of the view that you need to have experienced being a police officer at all ranks to be a good police leader. This poses serious issues for FT and DE officers, as those officers who have rapidly climbed the promotion ladder without serving their time on the streets, are regarded with some suspicion (Rowe 2006).

At the same time, officers suggest that their current leadership is poor, as they have forgotten what it is like to be an officer. Existing leadership therefore shares an identity problem with DE and FT officers, which they must address if they want to influence and guide the police service during this period of change and uncertainty. Questions need to be raised about the future of police leadership and how it can address this identity dilemma. This paper suggests that police leaders (DE, FT and existing) need to convince officers that they understand, represent, and can advance the interests of the police and has identified potential ways in which this might be achieved from previous research (Anderson et al. 2002; Toch 2008; Sklansky and Marks 2008; Steinheider and Wuestewald 2008; Wood et al. 2008; Haake et al. 2015). If they can achieve this, then evidence from social and organizational psychology suggests that they will be regarded as more trustworthy, fair, and charismatic and therefore more able to influence and lead junior officers and make decisions that would otherwise be unpopular (Haslam et al. 2001; Reicher et al. 2005).

In a period where policing in England and Wales is facing some of the biggest and most controversial challenges of the last 60 years (Brain 2013), if police leaders are able to develop and direct a shared sense of us within policing, they will be able to galvanize their junior officers' otherwise idiosyncratic motivations and harness the transformative power of their coordinated energies (Ellemers et al. 2004). Thus, by understanding the importance of identity, police leaders can create more propitious conditions within which junior officers will follow their leadership.

Acknowledgements This work was supported by the Constables Central Committee of the Police Federation of England and Wales (grant number P43F1506).

Funding Constables Central Committee of the Police Federation of England and Wales P43F1506.

\section{Compliance with Ethical Standards}

Conflict of Interest The authors declare that they have no conflict of interest.

Ethical Approval University Faculty Ethics approval HLS-HASS-11029 .

Informed Consent Yes.

Open Access This article is distributed under the terms of the Creative Commons Attribution 4.0 International License (http:// creativecommons.org/licenses/by/4.0/), which permits unrestricted use, distribution, and reproduction in any medium, provided you give appropriate credit to the original author(s) and the source, provide a link to the Creative Commons license, and indicate if changes were made.

\section{References}

Agresti A (2007) An introduction to categorical data analysis. Wiley, Hoboken

Anderson GS, Litzenberger R, Plecas D (2002) Physical evidence of police officer stress. Polic Int J Police Strateg Manag 25(2):399-420 
Bass BM (1985) Leadership and performance beyond expectations. Free Press, New York

Berson Y, Dan O, Yammarino FJ (2006) Attachment style and individual differences in leadership perception and emergence. J Soc Psychol 146(2): 165-182

Boyle A (1962) Trenchard, man of vision. Collins, London

Brain T (2013) The future for policing in England and Wales. Oxford University Press, Oxford ISBN: 9780199684458

Braun V, Clarke V (2006) Using thematic analysis in psychology. Qual Res Psychol 3(2):77-101

Bryman A, Stephens M, Campo C (1996) The importance of context: qualitative research and the study of leadership. Leadersh Q 7(3): 353-370

Caless B (2011) Policing at the top: the roles, values and attitudes of chief police officers. Policy Press, Bristol

Cockcroft T (2014) Police culture and transformational leadership: outlining the contours of a troubled relationship. Polic Int J Police Strateg Manag 8(1):5-13

College of Policing (2015) Leadership review. Recommendations for delivering leadership at all levels. http://www.college.police.uk/ What-we-do/Development/Promotion/the-leadership-review/Pages/ The-Leadership-Review.aspx

Dinh JE, Lord RG, Gardner WL, Meuser JD, Liden RC, Hu J (2014) Leadership theory and research in the new millennium: current theoretical trends and changing perspectives. Leadersh Q 25(1):36-62

Dobby J, Anscombe J, Tuffin R (2004) Police leadership: expectations and impact. Home Office Research, Development and Statistics Directorate, London

Dodd V and Stratton A (2011) Bill Bratton says he can lead police out of 'crisis' despite budget cuts. The Guardian newspaper, 14 August 2011. http://www.guardian.co.uk/uk/2011/aug/14/bill-brattonpolicecrisis-cuts

Ellemers N, de Gilder D, Haslam SA (2004) Motivating individuals and groups at work: a social identity perspective on leadership and group performance. Acad Manag Rev 29(3):459-478

Finn P (1997) Reducing stress: an organization-centered approach. FBI Law Enforcement Bull 66(8):20-26

Firmin RL, Bonfils KA, Luther L, Minor KS, Salyers MP (2017) Using text-analysis computer software and thematic analysis on the same qualitative data: a case example. Qualitative Psychol 4(3):201-210

Giessner SR, Van Knippenberg D, Sleebos E (2009) License to fail? How leader group prototypicality moderates the effects of leader performance on perceptions of leadership effectiveness. Leadersh Q 20(3): $434-451$

Glaser BG, Strauss AL (1967) The discovery of grounded theory: strategies for qualitative research. Aldine, New York

Haake U, Rantatalo O, Lindberg O (2015) Police leaders make poor change agents: leadership practice in the face of a major organisational reform. Polic Soc 25(1):1-15

Haslam SA (2001) Psychology in organizations: the social identity approach. Sage, London and Thousands Oaks

Haslam SA, Platow MJ, Turner JC, Reynolds KJ, McGarty C, Oakes PJ, Johnson S, Ryan MK, Veenstra K (2001) Social identity and the romance of leadership: The importance of being seen to be 'doing it for us'. Group Process Intergroup Relat 4(3):191-205

Haslam SA, Reicher SD, Platow MJ (2011) The new psychology of leadership: identity, influence and power. Psychology Press, London and New York

Her Majesty's Inspectorate of Constabulary (2013) Policing in austerity: rising to the challenge, Her Majesty's inspectorate of constabulary. Home Office, London
Hoggett J, Redford P, Toher D, White P (2014) Challenge and change: police identity, morale and goodwill in an age of austerity. UWE, Bristol

Home Office (2017) Police workforce, England and Wales, 30 September 2016. ISBN 978-1-78655-332-4, Home Office Statistical Bulletin 0217

Judge TA, Bono JE, Ilies R, Gerhardt MW (2002) Personality and leadership: a qualitative and quantitative review. J Appl Psychol 87(4): 765-780

Kerr S, Jermier JM (1978) Substitutes for leadership: their meaning and measurement. Organ Behav Hum Perform 22(3):375-403

Krimmel JT (1996) The performance of college-educated police: a study of self-rated police performance measures. Am J Police 15(1):85-96

La Pelle N (2004) Simplifying qualitative data analysis using general purpose software tools. Field Methods 16(1):85-108

Lee M, Punch M (2004) Policing by degrees: police officers' experience of university education. Polic Soc 14(3):233-249

Leishman F, Savage SP (1993) Officers or managers? Direct entry into British police management. Int J Public Sector Manag 6(5)

Mastrofski SD (2002) The romance of police leadership. In: Waring E, Weisburd D (eds) Crime and Social Organization. Transaction Publishers, New Brunswick, pp 153-196

Mastrofski SD (2006) Police organization and management issues for the next decade. National Institute of Justice, Washington DC

Miles MB, Huberman AM (1994) Qualitative data analysis: an expanded sourcebook, 2nd edn. Sage, Thousand Oaks

Neyroud P (2011) Review of police leadership and training. Home Office, London

Platow MJ, van Knippenberg D (2001) A social identity analysis of leadership endorsement: the effects of leader ingroup prototypicality and distributive intergroup fairness. Personal Soc Psychol Bull 27(11):1508-1519

Platow MJ, Haslam SA, Foddy M, Grace DM (2003) Leadership as the outcome of self-categorization processes. In: van Knippenberg D, Hogg MA (eds) Leadership and power: identity processes in groups and organizations. Sage, London, pp 34-47

Reicher S, Haslam SA, Hopkins N (2005) Social identity and the dynamics of leadership: leaders and followers as collaborative agents in the transformation of social reality. Leadersh Q 16(4):547-568

Rowe M (2006) Following the leader: front-line narratives on police leadership. Polic Int J Police Strateg Manag 29(4):757-767

Schafer JA (2009) Developing effective leadership in policing: perils, pitfalls, and paths forward. Polic Int J Police Strateg Manag 32(2): 238-260

Schafer JA (2010) Effective leaders and leadership in policing: traits, assessment, development, and expansion. Polic Int J Police Strateg Manag 33(4):644-663

Schaveling J, Blaauw S, van Montfort K (2017) Predictors of group performance in a police criminal investigation department: the role of gender homogeneity, leadership and team characteristics. J Police Crim Psychol:1-11

Seidman I (2013) Interviewing as qualitative research: a guide for researchers in education and the social sciences. Teachers college press, New York

Sklansky DA, Marks M (2008) The role of the rank and file in police reform. Polic Soc 18(1):1-6

Steffens NK, Haslam SA, Reicher SD (2014) Up close and personal: evidence that shared social identity is a basis for the 'special' relationship that binds followers to leaders. Leadersh Q 25(2):296-313

Steinheider B, Wuestewald T (2008) From the bottom-up: sharing leadership in a police agency. Police Pract Res 9(2):145-163 
Subašić E, Reynolds KJ, Turner JC, Veenstra KE, Haslam SA (2011) Leadership, power and the use of surveillance: implications of shared social identity for leaders' capacity to influence. Leadersh Q 22(1):170-181

Tajfel H, Turner JC (1979) An integrative theory of intergroup conflict. Social Psychol Intergroup Relat 33(47):74

Toch H (2008) Police officers as change agents in police reform. Polic Soc 18(1):60-71

Van Maanen J (1978a) On watching the watchers. Policing: A view from the street. Goodyear, Santa Monica

Van Maanen J (1978b) The asshole. Policing: A view from the street. Goodyear, Santa Monica
Weber RP (1990) Basic content analysis, 2nd edn. Sage, Newbury Park Winsor T (2011) Independent review of Police officers' and staff renumeration and conditions. Part one report. Her Majesties Stationery Office, London

Winsor T (2012) Independent review of Police officers' and staff renumeration and conditions. Part two report. Her Majesties Stationery Office, London

Wood J, Fleming J, Marks M (2008) Building the capacity of police change agents: the nexus policing project. Polic Soc 18(1):72-87

Zaller J, Feldman S (1992) A simple theory of the survey response: answering questions versus revealing preferences. Am J Polit Sci 36(3):579-616 